\title{
DESIGN AND EFFICIENCY OF AN ASYMMETRIC GEAR
}

\section{BALAMBICA ${ }^{1}$, VISHWA DEEPAK ${ }^{2}$ \& SUSHANT KUMAR ${ }^{3}$}

${ }^{I}$ Associate Professor, Department of Mechanical Engineering,

Bharath Institute of Higher Education and Research, Agharam Road, Selaiyur, Chennai, Tamil Nadu, India

${ }^{2}$ Student, Department of Mechanical Engineering,

Bharath Institute of Higher Education and Research, Agharam Road, Selaiyur, Chennai, Tamil Nadu, India

${ }^{3}$ Assistant Professor, Department of Mechanical Engineering,

GKM College of Engineering, Chennai, Tamil Nadu, India

ABSTRACT
Presently, Gears suffer backlash as well as interference and undercutting. These defects can be eliminated by
increasing the pressure angle or by increasing the addendum of the matting gear design for many years. In additional
alteration, which is very rarely used is to make the gears Asymmetric mesh gear drive, means that larger and smaller
pressure angles are applied for the driving side and coast side, respectively.
To obtain the effect of the above spur gear, tooth parameters are to be designed and modelled. Later, the pinion
and gear in mesh is fabricated.
KEYWORDS: Gear, Asymmetric Gear, Design \& Gear Drive Mesh

Received: Feb 28, 2019; Accepted: Mar 19, 2019; Published: Apr 16, 2019; Paper Id.: IJMPERDJUN201925

\section{INTRODUCTION}

There has been a lot of research activity on spur gears with asymmetric teeth. New gear designs are needed because of the increasing performance requirements, such as high load capacity, high endurance, low cost, long life, and high speed. In some applications, gears experience only unidirectional loading. In this instance, the geometry of the drive side does not have to be symmetric to the coast side. This allows for the design of gears with asymmetric teeth. These gears provide flexibility to designers due to their non-standard design. If they are correctly designed, they can make important contributions to the improvement of designs of gears.

\section{ASYMMETRIC GEAR}

The two profiles (sides) of a gear tooth are functionally different for most gear drives. The workload on one profile is significantly higher and/or is applied for longer periods of time than for the opposite one. The design of the asymmetric tooth shape reflects this functional difference.

\section{Advantages}

The Profile performance provides,

- $\quad$ Load capacity is high

- Less weight 
- $\quad$ Noise is reduced

- Vibration is reduced

\section{Disadvantages}

- $\quad$ The problem is with the manufacturing of asymmetric gears.

- Additional optimization is required like circular top relief has to be applied in order to make the improvement visible.

\section{LITERATURE SURVEY}

A.L. Kapelevich [1] in his paper discusses the design of asymmetric tooth gears to improve performance of the primary drive flank profiles at the expense of the opposite coast profiles' performance. The coast flanks are unloaded or lightly loaded during a relatively short work period. Such gears should be used for unidirectional or mostly unidirectional load transmission, when the coast flanks are unloaded or lightly loaded during relatively short work time.

This paper describes a gear geometry analysis and the asymmetry factor and tooth root fillet optimization of epicycling stages, with singular and compound planet gears. This allows for a considerable increase in power transmission density, increase in load capacity, and reduction in the size and weight of asymmetric epicyclic gear drives.

Sharatchandrai R Karagi[ 2 ] in his paper discusses the effect of pressure angle and back up ratio on asymmetric spur gear tooth bending stress. The main objective of the present work is, to estimate the stress across the critical section for different backup ratios and the results obtained. Developed programme is used to create a finite element model for asymmetric spur gear tooth to study the effect of bending stress at the critical section for different backup ratios.

This paper describes the two profiles (sides) of a gear tooth that are functionally different for many gears. The workload on one profile is significantly higher and is applied for longer periods of time than for the opposite one. The design of the asymmetric tooth shape reflects this functional difference. And, he concluded that these types of gears find application in light weight high power aircraft transmission.

A.Kapelevich [3] in his paper discussed, asymmetric teeth shape reflects this functional difference. Design intent of asymmetric gear teeth is to improve performance of the primary drive profiles at the expense of the performance off the opposite coast profiles. The coast profiles are unloaded, or lightly loaded during a relatively short work period. Asymmetric tooth profiles also make it possible simultaneously, to increase the contact ratio and operating pressure angle beyond the conventional gear limits.

Asymmetric and baseline (symmetric) toothed gear test specimens were designed, fabricated and tested to experimentally determine their single-tooth bending fatigue strength and scuffing resistance. The gear test specimens are presented. Similarly, the scuffing test gears are within the design experience range of typical main transmission helicopter power gears.

A.Kapelevich[ 4 ] in his paper discussed, an Alternative Direct Gear Design method [1] defines the gear tooth geometry without using standard generating rack tooling profiles. It is an application-driven gear geometry development process with a primary emphasis on performance maximization and cost efficiency, without concern for any predefined tooling parameters. This means that the gear parameters are primary and the manufacturing process and tool parameters are 
secondary.

Two involutes of the base circle, the arc distance between them, and tooth tip circle describe the gear tooth. This is especially critical for plastic gears. Plastics do not conduct heat as well as metal. Heat accumulates on the gear tooth surface, leading to premature failure. In Direct Gear Design, a fillet profile is optimized in order to minimize the bending stress concentration [1].

A.Kapelevich [5] in his paper introduces an analytical approach that describes main gear mesh characteristics such as operating pressure angles, contact ratios, specific sliding velocities and gear mesh efficiency as functions of the pitch factors. It also considers areas of existence of involute gear pairs with the given constant values of the pitch factors.

Two involute curves unwound from the base circle, the arc distance between them, and tooth tip circle describe a gear tooth profile. The equally spaced teeth form the gear. The root fillet profile connecting neighbouring tooth flanks is not in contact with the mating gear teeth. However, this portion of the tooth profile is critical because, this is the area of the bending stress concentration. It is designed to exclude any kind of interference with the mating tooth tip and minimize bending stress.

\section{DESIGN}

\section{Input Parameters}

\section{Pinion}

Pressure angle at drive side in degree, $\alpha_{\mathrm{d}}=\mathbf{3 0}^{\mathbf{0}}$

\section{Gear}

Assume pressure angle at drive side, $\alpha_{\mathrm{d}}=30^{\circ}$

Assume pressure angle at coast side, $\alpha_{c}=15^{\circ}$

Other dimension is same as the standard pinion

Pitch circle diameter, $\mathrm{d}_{2}=246 \mathrm{~mm}$

Addendum circle diameter, $\mathrm{d}_{\mathrm{a} 2}=251 \mathrm{~mm}$

Dedendum Circle diameter, $\mathrm{d}_{\mathrm{f} 2}=231 \mathrm{~mm}$

Base circle diameter on drive side, $=246 \cos 30^{\circ}$

$=213.04 \mathrm{~mm}$

Base circle diameter on drive side,$=\mathbf{2 3 7 . 6 7} \mathbf{~ m m}$

\section{Shaft Calculations}

\section{Material}

C45 - cold drawn annealed, $\sigma_{\mathrm{y}}=340 \mathrm{~N} / \mathrm{mm}^{2}$

$[\sigma]=113.33 \mathrm{~N} / \mathrm{mm}^{2}$

Factor of safety $=3$ 


$$
\begin{aligned}
& {[\sigma]=0.5[\sigma]=0.5 \times 113.33=\mathbf{5 6 . 6 6} \mathbf{~ N} / \mathbf{m m}^{2}} \\
& {[\sigma]=56.66 \times 0.75=42.5 \mathrm{~N} / \mathrm{mm}^{2} \text { (Accounting for key way) }}
\end{aligned}
$$

\section{Gear Shaft Calculation}

Resultant bending moment $=103.417 \mathrm{Nm}$

Equivalent Torque Calculation:

$$
\text { Assume } \mathrm{K}_{\mathrm{b}}=1.5, \quad \mathrm{~K}_{\mathrm{t}}=1
$$

Equivalent torque at $\mathrm{C}$

$=513.38 \mathrm{Nm}$

\section{Diameter Calculation}

$\leq[42.5]$

$\mathrm{d}=39.48 \approx 40 \mathrm{~mm}$ (Standard) Equivalent Torque Calculation:

Assume $\mathrm{K}_{\mathrm{b}}=1.5 \quad \mathrm{~K}_{\mathrm{t}}=1$

$\mathrm{T}_{\mathrm{EC}}=$ Equivalent torque at $\mathrm{C}$

$=211.1469 \mathrm{Nm}$

\section{Diameter Calculation}

$\mathrm{d}=\mathbf{2 9 . 3 6} \approx \mathbf{3 0} \mathrm{mm}($ Standard $)$

\section{Efficiency of Spur Gear Pairs:}

Efficiency, $\boldsymbol{\eta}=\frac{\text { Output Power }}{\text { Input Power }}$

\section{Standard Gear Efficiency}

Average relative sliding velocity,

Where,

$\mathrm{PQ}_{\max }=\mathrm{is}$ the maximum distance of $\mathrm{Q}$ from $\mathrm{P}$

Powerless due sliding

$P_{s}=V_{a} F_{N} \mu$

Where,

$F_{N}=$ Normal gear force

The coefficient of friction $\mu$ depends on the material, finish of tooth surface and state of lubrication. It is not of a constant value, but varies with load changes, velocity changes etc. Besides the above determining factors, Average value of $\mu$ can be taken as around 0.07 . 


\section{Efficiency}

\section{Standard Gear Drive}

Through measurement from the diagram we get the PQ value as $13.2307 \mathrm{~mm}$.

$$
\begin{aligned}
& \mathrm{F}_{\mathrm{N}}=\frac{5400}{\cos 20}=5746.56 \mathrm{~N} \\
& \mathrm{~V}=\frac{2 \pi \mathrm{n}}{60} \times \frac{72}{2 \times 1000} \\
& =\frac{2 \pi \times 1200 \times 72}{60 \times 2 \times 1000} \\
& =4.5238 \mathrm{~m} / \mathrm{sec} \\
& \mathrm{V}_{\mathrm{a}}=\frac{1}{2}\left[\frac{13.2307}{1000} \times \frac{4.5238}{3.4166 \times 0.036} \times(3.4166+1)\right] \\
& 1.0746 \mathrm{~m} / \mathrm{sec} \\
& \text { Power loss due to sliding }= \\
& 1.0746 \times 5746.56 \times 0.07=432.26 \text { watts. } \\
& \eta=\frac{18000-432.26}{18000} \times 100 \\
& =97.5 \%
\end{aligned}
$$

\section{Asymmetric Gear Drive}

$\mathrm{PQ}=11.6 \mathrm{~mm}$

$\mathrm{V}=4.5238 \mathrm{~m} / \mathrm{sec}$

$\mathrm{V}_{\mathrm{a}}=\frac{1}{2}\left[\frac{11.6}{1000} \times \frac{4.5238}{3.4166 \times 0.036} \times(3.4166+1)\right]$

$0.9421 \mathrm{~m} / \mathrm{sec}$

Power loss due to sliding $=$

$0.9421 \times 5746.56 \times 0.07=432.26$ watts.

$$
\begin{aligned}
& \boldsymbol{\eta}=\frac{18000-411.2046}{18000} \times 100 \\
& =\mathbf{9 7 . 7} \%
\end{aligned}
$$

\section{Design details of Asymmetric Gear Pair}

Table 1: Shared Attribution

\begin{tabular}{|l|c|c|}
\multicolumn{1}{|c|}{$\begin{array}{c}\text { Shared } \\
\text { Attributes }\end{array}$} & \multicolumn{2}{c|}{$\begin{array}{c}\text { Asymmetric gear } \\
\text { pair }\end{array}$} \\
\hline Parts & Pinion & Gear \\
\hline Number of teeth & 12 & 41 \\
\hline Module in mm & 6 & 6 \\
\hline Centre distance in mm & \multicolumn{2}{|c|}{171} \\
\hline Face Width B in mm & \multicolumn{2}{|c|}{50} \\
\hline Torque in Nm & 300 & 1027.7229 \\
\hline
\end{tabular}




\begin{tabular}{|l|c|c|}
\hline \multicolumn{2}{|c|}{ Table 1: Contd., } \\
\hline \multirow{3}{*}{ Pressure angle in Degree } & Coast side & Coast side \\
\cline { 2 - 3 } & $15^{\circ}$ & $15^{\circ}$ \\
\cline { 2 - 3 } & & Drive side \\
\cline { 2 - 3 } & $30^{\circ}$ & $30^{\circ}$ \\
\hline Tooth thickness in $\mathrm{mm}$ & \multicolumn{2}{|c|}{11} \\
\hline Contact Ratio & \multicolumn{2}{|c|}{1.311} \\
\hline Gear Efficiency in \% & \multicolumn{2}{|c|}{97.7} \\
\hline
\end{tabular}

\section{PARTS AND ASSEMBLY DRAWINGS}

\section{Isometric View of Pinion}

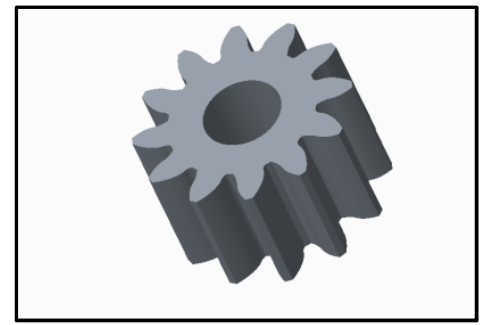

Figure 1: Isometric View of Pinion

\section{Isometric View of Gear}

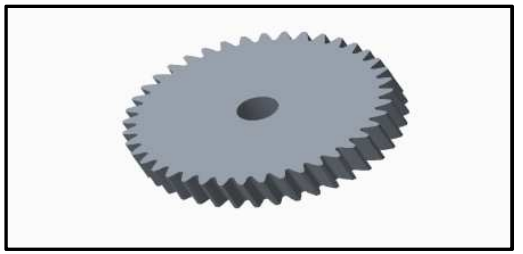

Figure 2: Isometric View of Gear

\section{CONCLUSIONS}

The asymmetric gear in mesh for industrial purpose has been designed using standard gear formula and Lewis Buckingham Equation. And, Modelled in Creo parametric 2.0 of PTC, then it has been fabricated using 3d printer after converting them into stl file. Later, it has been assembled using two shafts and one handled in mesh. This way unidirectional asymmetric gear drive has been fabricated successfully in fully operational condition.

\section{REFERENCES}

1. Design of Transmission Elements, T.J Prabhu.

2. Design Data, PSG college of Technology.

3. A.L. Kapelevich, "Analysis And Optimization Of Asymmetric Epicyclic Gears", Presented at the International Conference On Gears, Garching near Munich, Germany, October 5-7 2015. It was also published in Gear solutions, August 2016, 50-55f.

4. Sharadchandarai R Karagi, "Effect Of Pressure Angle And Backup Ratio On The Asymmetric Spur Gear Tooth Bending Stress", Presented at the International Journal of Mechanical Engineering and Robotic Research on 4 October 2014.

5. A.L. Kapelevich, "Direct Gear Design For Asymmetric Tooth Gears", a fragments of the book V. Gold farb and N. Barmina (eds), Theory and practice of Gearing and Transmissions, Mechanism and Machine Science 34, Springer International Publishing, 2016, 117- 143. 
6. A.L. Kapelevich, T.M. mc namra, “Advantage Of Direct Gear Design For Automotive Polymer Gear Drives”, Plastic in motion conference, June 1-4 Dearborn, Mi. It was published in Gear Solutions, December 2015, 40- 46.

7. Muralimohan, N., Palanisamy, T., \& Vimaladevi, M. N. (2014). Experimental study on removal efficiency of blended coagulants in textile wastewater treatment. IMPACT: International Journal of Research in Engineering \& Technology, 2(2), $15-20$.

8. A.L. Kapelevich, "Pitch Factor Analysis For Symmetric And Asymmetric Tooth Gear", International Gear Conference 2014, Conference Proceedings Volume 1, August 26-28 2014, Lyon, France.

9. T. J. Prabhu, Design of Transmission Elements. 1996-2008.pp.1.1-1.23, 7.1 [1]

10. V. Balambica, T. Madhan Raj, C. Dinesh, A. Mohamed Azharudeen2 \& K. Harish., Influence Of Stresses In A Modified NonMetallic Spur Gear Pair”., Issue 6,Dec 2018, pp 239-248.,International Journal of Mechanical and Production Engineering Research and Development (IJMPERD)., Transtellar Journal Publications., Vol. 8.,ISSN (P): 2249-6890; ISSN (E): 2249 8001 .

11. V. Balambica, R. Sachin Ritto, B. Balamuralidharan, T. Rajadurai \& A. Akthar.," Effect Of Negative Correction Factor In Spur Gear Tooth Profile Using Fea”., Issue 2,Dec 2018, pp 1-6., International Journal of Industrial Engineering \& Technology (IJIET).,Transtellar Journal Publications., Vol. 8., ISSN (P): 2277-4769; ISSN (E): 2278-9456.

12. Shrivastava, D., \& Malik, M. M. (2014). Enhancing efficiency of organic light emitting diodes through doping of cadmium sulphide nanocrystals. Int. J. Nanotechnol. Appl., 4(1).

13. Dr. V. Balambica., Vishwa Deepak, "Study and Analysis of Reducing Hand Vibration in Tractor"., November 2017.,PP 275279.,International Journal of Pure and Applied Mathematics., Publisher Academic Publications Ltd., Volume 116.,Special.,ISSN Print 1211-8080.,ISSN Online-1394-3395. 
